\title{
Research on "4A" Model of Museum Social Education Based on U-Learning Theory
}

\author{
Yanjun Song, Kefeng Li, Lu Sun \\ China Sanxia Museum, Chongqing, Yuzhong District, Chongqing, 400020; \\ Chongqing Second Normal University, Chongqing University of Posts and Telecommunications, Nanan District, Chongqing, \\ 400060
}

\begin{abstract}
Under the background of the current realization of the Chinese Dream of national rejuvenation, the U-Learning theory is applied to the museum social education to actively explore the "4A" model of museum social education to make museums carry out social education activities to anyone, at anytime and anywhere with any device to further develop their social education function and role.
\end{abstract}

\section{Keywords-U-Learning; museum; social education; $4 A$ model}

\section{CONCEPT AND CHARACTERISTICS OF MUSEUM SOCIAL} EDUCATION

\section{A. Concept of museum social education}

Education refers to social practice activities that influence people's physical and mental development, that is, in accordance with laws, regulations and industrial norms, educators educate and cultivate the mental development of educatees in a purposeful, planned, and organized manner according to school conditions and professional titles (1) . Based on the educational objectives of the party and the government, guided by the socialism with Chinese characteristics in the new era of Xi Jinping, the museum social education is intuitive education activities for the audience through the display formed by physical objects and other auxiliary forms. In the museum masterpiece of Museums for a New Century in 1984, it "compares education to the soul of a museum". In 2015, China promulgated the Museum Ordinance, clarifying that museum integrate education, research and appreciation. Museums are comprehensive education fields that carry out local conditions and customs, natural scenery, artistic relics, and technological innovation, as well as social education activities that are closely related to people's production and life, economic politics, culture and entertainment, etc. towards the entire society, winning increasing attention of the party and the government. Museums fulfill their social responsibilities and conducts museum education towards the society, and have become an important classroom for off-campus education of students at all levels and lifelong education of adults, being praised as a social university without walls by schools, the society and families.

\section{B. Characteristics of museum social education}

The museum education has the characteristics of objectivity, ideological content, pleasure autonomy, etc. Objectivity means that museums reflect the scientific content and the original appearance of things with the objective and authentic visualized cultural relics and specimens, and creates conditions for the audience to know things intuitively and emotionally during the viewing process. Ideological content means that museums must adhere to the direction of socialist, strengthen the ideals and beliefs of communism, shape and cultivate people with socialism with Chinese characteristics in the new era of Jinping XI, integrate the core value of socialism into museum social education, cultivate the audience's world outlook, outlook on life and values. Pleasure means that the education activities of museums integrate patriotism, scientific knowledge, humanistic knowledge, aesthetic knowledge, etc. with appreciation and entertainment to achieve the purpose of being educated silently during the unconscious physical and mental pleasure. Autonomy means that the scale, form and venue of museum education activities are flexible, and many activities can be held in open forms, and the audience can join or leave at any time, and no one is forced to learn; there are no prescribed courses and learning progress; the education is everywhere, and the educatees complete self-learning and education in an open environment ${ }^{(2)}$.

\section{COMBINATION OF U-LEARNING AND MUSEUM SOCIAL EDUCATION}

\section{A. Concept and characteristics of U-Learning theory}

The term "U-Learning" comes from "Ubiquitous Computing" and it is proposed by the American Mark. Weiser. "U" represents Ubiquitous ${ }^{3}$. U-Learning refers to learning activities that are ubiquitous and communicated at any time, that is, anyone can use the information technology to learn at anytime, anywhere with any device, which is called the "4A" model of the U-Learning theory ${ }^{(4)}$. U-Learning is mainly characterized by ubiquity, interactivity, and situationality. Ubiquity refers to the way that learners carry out the learning to solve problems at anytime, anywhere based on their own needs. Current social platforms such as mobile network, APP WeChat, Weibo, and QQ all provide a wide range of learning support and random learning possibilities. Interactivity:

\footnotetext{
${ }^{(1)}$ Re-understanding of Labor Education in Colleges and Universities in the New Era and Construction of "1+3" Practice System, Zhijun YI, Wen PEI, Think Tank Era, May 31, 2019

${ }^{2}$ The Social Responsibility and Social Education of Museum, Jixiang SHAN, Southeast Culture, December 28, 2010

${ }^{3}$ Literature Review in Ubiquitous Learning Theory-Internet Documentation Resources (http://www.360doc.co)

${ }^{(4)}$ Application of Ubiquitous Learning in Computer Network Course Teaching, Tang Chunlan, Journal of Chengdu Aeronautic Polytechnic, September 19, 2018.
} 
learners use various forms and platforms of "Internet+" to have dialogue with technology, environment, expert and other learners, creating an infinite interactive learning field with wireless smart space. Situationality means that learners imperceptibly carry out various learning activities in the intelligent learning field environment, which truly reflects that learners are in the situation while the situation contains the learners, giving full play to the role of environmental education, situational education, and education for everyone, and creating an imperceptible learning scene.

\section{B. The U-Learning theory leads the development of museum social education}

San Francisco Museum of Mexico first used the ULearning theory to create an electronic guide for the museum, allowing the audience to prepare for the visit before the exhibition, carry out interactive activity experience during the exhibition, and search the museum webpage for information needed by them at any time according to their interests, which embodies the U-Learning characteristics of the "typical informal learning space, experience with the body and think with the head". With the purpose of "museum-based 24-hour campus space", Virginia Tech in South Africa carries out the campus learning program of awakening Ubiquitous, and designs a museum-based future campus for all students to participate in learning through strong cooperation between museums and schools ${ }^{(5)}$. In recent years, with the rapid development of network technology, U-Learning has begun to appear in a variety of education situations - - mixed classrooms in schools, interactions in museums, language learning in life, etc. Especially in the era of 5G technology, based on the U-Learning theory, it has become possible to give full play to the rich collection resources of museums and greatly improve the effect of museum social education.

\section{EXPLORATION OF THE MUSEUM SOCIAL EDUCATION ROUTE BASED ON THE U-LEARNING THEORY}

Integrate the U-Learning theory into the museum social education, namely, the " $4 \mathrm{~A} "$ model that anyone can learn at anytime, anywhere with any device, to better play the functions and roles of museum social education.

\section{A. The museum social education is carried out for anyone}

The first is to strengthen the quality education of citizens. In order to improve the overall quality of citizens, the party and the government attach great importance to the social education function of museums. The groups attending museums not only present a diversified trend in composition, but also show a completely different diversity in the way, purpose and demand of using the museums. Firstly, the cultivation of the comprehensive quality of citizens needs museums to play important roles. When people's material needs reach a certain level, they must have spiritual needs. For example, the pursuit of culture and art. The precious cultural relics and artworks in museums are hard to see outside, and it is their rarity that attracts the audience. Secondly, museums strive to use their own unique resources to improve the comprehensive quality of the audience. As public welfare

\footnotetext{
${ }^{(5)}$ Literature Review in Ubiquitous Learning Theory -Internet Documentation Resources (http://www.360doc.co)

${ }^{(6)}$ Exploration and Analysis of Thoughts on Giving Full Play to the Function of Museum Social Education Function, Ruiying LI, Social Sciences Review, November 15, 2015.
}

institutions, based on the principle of serving the people highly, museums try every means to promote and introduce the physical objects and exhibits in them to the audience to make them come with pleasure and happily leave with knowledge, thus being happy to spread the cultural value, and making the vitality of museums become increasingly strengthened due to social education activities.

The second is the second class that assists the adolescent. As an important cultural hall, museums are the second class for the adolescent to learn history, cherish the present, and move towards the future. After visiting museums, unforgettable viewing experience will be left in the heart of the adolescent. Combined with the characteristics of the adolescent's full of life, curiosity, experience and acquisition of knowledge, establish the formative education philosophy of museums, start from telling moving stories around, speak from changes of the city, tell about the heroes, historical events, cultural development and special resources of the hometown, etc. to the adolescent to make them consciously cultivate the hometown feelings of urban civilization, Chinese culture and regional customs, to make them move towards the future with hometown feelings and come back with homesickness for construction. The organizers of museum social education shall follow the physical and mental characteristics of the adolescent when designing activities, and help them transform and sublimate their world outlook, outlook on life and values, and cultivate their responsibility of advocating culture and loving the motherland. Only happy learning can make the learning long-lasting, and make them enrich knowledge and cultivate feelings in happiness.

\section{B. The museum social education is carried out anytime}

The first is to spread Chinese culture at any time. The exhibits in museums are mostly important cultural relics of our country, representing the development and historical process of Chinese traditional culture. They are the rich heritage inherited from history, the crystallization of the wisdom of the Chinese nation, and the witness of the splendid civilization of the Chinese nation ${ }^{(6)}$. Through them, patriotism education can be better carried out to the adolescent to consolidate their behavior foundation. For example, the annual activities of the Chinese New Year series of the China Three Gorges Museum, Chongqing: "Chinese Zodiac Exhibition", "Grain Adolescent of the Laba Rice Porridge Festival", "Write Fu \& Celebrate the Beginning of Spring", "Flashing of New Year's Blessing", "Blessed Dog Welcomes the New Year, Back to Back of Dogs", "Make Festive Lanterns, Welcome the New Year", "New Year Comes, New New Year Pictures", "Cut Paper-cut for Window Decoration, Celebrate the New Year", etc. Focusing on the festivals and holidays such as "May Day", "Dragon Boat Festival", and "National Day", education activities such as "go back to the ancient times, and learn labor from the ancients", "when pouch meets Sichuan embroidery", "talk about Mid-Autumn Festival at the museum", and "welcome the National Day with flags" are carried out to make the public inherit the Chinese culture and cultivate the patriotism in the museum social education.

The second is that the media spreads and creates education at any time. Museums at all levels shall fully cooperate with 
the news media to combine the small class of culture and museum together with the big class of the society to maximize the effect of the museum social education. The museum administrators shall adhere to the correct direction of running museums, establish the overall situation of museum social education, and rely on the news media to further enhance the social education effect and play the role of social education. The conduction of social education propaganda through modern technological means such as the museum's unique mobile APP, audio and video, digital simulation, Internet +, and audience interaction, and the expansion of the audience of museums not only can effectively promote museums' conduction of social education, but also can further improve the social status of museums in the hearts of the masses ${ }^{(7)}$. Museums can also design various advertisement forms such as novel and intimate subway advertisements, bus advertisements, car advertisements, TV and movie advertisements to enhance their social education effect.

\section{The museum social education is carried out anywhere}

The first is to achieve the digitalization of museum collections. Museums shall collect all the important cultural relics in their collections with high-precision model textures, and display cultural relics to the public with the all-round three-dimensional scanning technology and image stitching technique to improve the public's interest in cultural relics. Multimedia libraries can be established in museums to store corresponding texts, images, animations and audios, etc., and the way that combines pictures and texts shall be adopted to explain the exhibition to the masses to ensure their understanding of the exhibition of museums at the first time. Multimedia technology, three-dimensional technology and sound and light equipment technology shall be applied to display the cultural relics collected by museums in an all round way. Together with multiple auxiliary means such as images, pictures, and sounds, the connotation of the cultural relics can be fully displayed. And the way that restores historical scenes can even be applied to display their historical value ${ }^{(8)}$. For example, the naked eye 3D - "Yangtze River Three Gorges Hydroelectric Power Pivotal Project", "Ancient Chongqing Ancient Map MR", "Old Gate" cartoons, smart guide APP and video explanations, etc. of China Three Gorges Museum, Chongqing are all well received by the audience.

The second is to carry out the "three enters" of museums. Regularly carry out the activities of the special exhibition of "enter schools, enter communities, and enter the network" of museums to guide the public actively enter museums. Enter schools. Museums shall establish cooperation mechanisms with primary and middle schools to regularly move the display of excellent contents to schools to make the adolescent can experience the strength and charm of museums while remaining within doors, and make museums become the second class with real meaning for the adolescent. Enter communities. Fully explore the collection resources of local museums, and regularly enter communities for itinerant exhibition. Provincial museums can explore the operating mechanism of large social education and the Internet of things, absorb and integrate mobile exhibition resources such as district and county museums, establish the mobile museum

\footnotetext{
${ }^{(7)}$ Several Ways to Expand the Museum Social Education Functions under the New Situation, Chunhua TANG, Identification and Appreciation to Cultural Relics, July 8, 2019

${ }^{8}$ Exploration on the Deepening of Museum Social Education Services in the New Era, Jinxing WANG, Media Forum, July 10, 2019

${ }^{(9)}$ Exploration on the Deepening of Museum Social Education Services in the New Era, Jinxing WANG, Media Forum, July 10, 2019
}

alliance, and go deep into poverty-stricken villages to carry out cultural poverty alleviation, and so on. Enter the network. Museums can use the superior resources of their own cultural relics and artworks to shoot film and television works. For example, the documentary film and television work of Masters in the Forbidden City is popular across the country, which makes the Palace Museum, through the propaganda of the film and television work, accelerate the public's recognition of museums, accelerate the propaganda and mobility of information, and bring the maximum social education effect.

\section{The museum social education is carried out with any device}

The first is to establish the own brands of museums. Museums shall be determined about the "four-confidence", bring out the cultural confidence of museums, explore the cultural deposits of museums, make the public actively participate in the social education activities of museums, and stimulate them as media producers and disseminators of museums. Museums can establish their own cultural brands according to their own characteristics and forms of cultural relics, and design cultural and creative products of various forms based on the collection of cultural relics and profound cultural heritage. For example, the Palace Museum has designed more than 9,000 kinds of cultural and creative products, including notebooks, earphones, mobile phone cases and other fields, which has not only greatly expanded the influence of the Palace Museum, but also created unexpected economic benefits, laying a more solid foundation for the development of the museum ${ }^{9}$

The second is to establish the group of museum experts. Museums shall strengthen exchanges with experts and scholars in related fields, regularly or irregularly hold some special lectures, and invite experts and scholars to give lectures. "Three Gorges Wenbo Lecture Room". For example, the Palace College cooperates with China Three Gorges Museum, Chongqing, and has successively invited many experts from the Palace Museum to give lectures in Chongqing. During the exhibition of the cooperative exhibition of "Shengyan" of the Southwest Museum Alliance, Mr. Laishun An, vice president of International Council of Museums, was specially invited to the museum to give the lecture entitled Optimize Resources and Vitalize Heritage - Rethinking on the Reform and Development of Chinese Museums. Museums shall focus on cultivating their own famous experts. Museum experts shall have certain relevant subject knowledge such as history, art history, archaeology, antiquities, museology, communication, education and educational psychology, together with observation, concentration, affinity and advocacy, etc., and improve their basic skills in terms of language expression, communication skills, emotional control and project management, and so on. Expert groups inside and outside museums shall regularly carry out theme lectures and explanations to make the masses have a more profound cognition and understanding of stories behind the cultural relics collected in museums, and let more people enjoy the social education services of museums.

Through the "4A" model practice of the museum social education, museums can truly enable anyone to carry out 
education activities at anytime, anywhere, with any device and maximize the social education effect of museums.

\section{ACKNOWLEDGMENT}

This paper is funded by the City Road $\bullet$ Chongqing Heroes comic creation research of 2019 Chongqing Social Science Planning Project.

Yanjun SONG (1976-), male, Han nationality, doctor, professor of China Sanxia Museum, Chongqing, main research direction: social education.

Kefeng LI (1976-), female, Han nationality, master, associate professor of Chongqing University of Education, main research direction: cultural resources development.

Lu SUN (1987-), male, Han nationality, doctor, associate professor of Chongqing University of Posts and Telecommunications, main research direction: Chinese modern culture.

\section{REFERENCE}

[1] Jixin PAN; Yaoceng LEI; Lulu CHENG; Hua SHI. Literature Review in Ubiquitous Learning Theory [J]. Journal of Distance Education, 2010, V.28; No.197, 95-100.

[2] Mingxiao CHEN. How to Deepen the Museum Social Education Services in the New Era [J]. Comparative Study of Cultural Innovation, 2019, v.3; No.75, 158-159.

[3] Jing WANG. Talking About the Social Responsibility and Social Education of Museums [J]. Identification and Appreciation to Cultural Relics, 2019, No. 153, 132-133.

[4] Jixiang SHAN. The Social Responsibility and Social Education of Museum [J]. Southeast Culture, 2010, No. 218, 11-18.

[5] Jinxing WANG. Exploration on the Deepening of Museum Social Education Services in the New Era [J]. Media Forum, 2019, v.2; No.37, 27-28.

[6] Wei LI. Discussion on the Function of Museum Social Education [J]. Technology Wind, 2018, No.341, 186-188. 